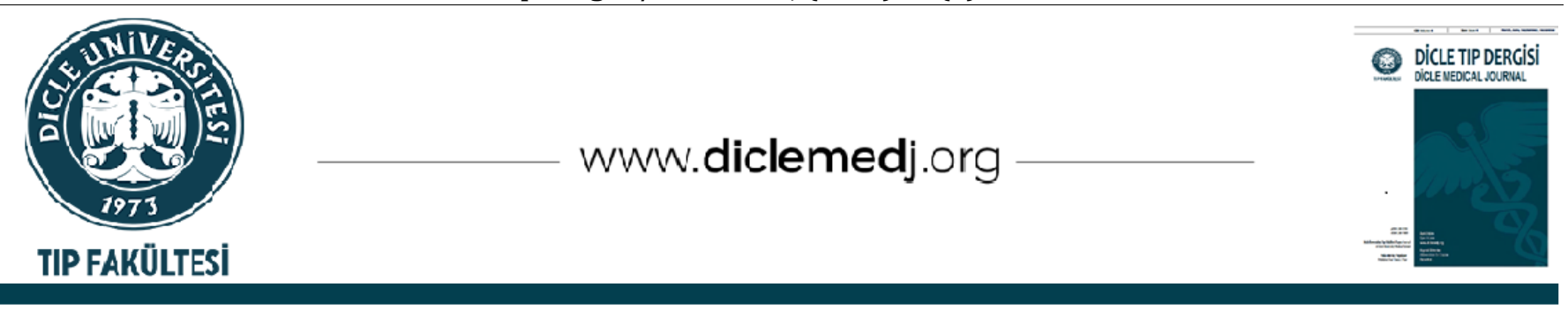

\title{
Türk Silahlı Kuvvetleri'de Görevli Sözleşmeli Er ve Erbaşlarda Görülen Kas İskelet Sistemi Yaralanmaların Profili
}

\author{
Tuğrul Ergün ${ }^{\mathrm{D}}$, Mehmet Korkmaz ${ }^{\mathrm{D}} 1$ \\ 1 T.C. S.B. Mardin Devlet Hastanesi Ortopedi ve Travmatoloji Kliniği, Mardin, Türkiye
}

Geliş: 18.01.2021; Revizyon: 09.06.2021; Kabul Tarihi: 14.06.2021

Öz

Giriş: Askerlik mesleği zorlu fiziksel eğitim koşulları barındırır ve yaygın kas iskelet sistemi yaralanmalarına yol açabilir. Bu çalışmanın amacı Türk Silahlı Kuvvetleri (TSK) bünyesinde sözleşmeli er ve erbaş olarak görev yapan askerlerde gözlenen yaygın kas iskelet sistemi yaralanmalarının profilini çıkararak bunları önlemeye yönelik geliştirilebilecek stratejilerine kaynak olmaktır.

Yöntemler: Veriler son bir yıl içinde rutin sağlık kontrolleri yapılan sağlıklı ve herhangi bir kas iskelet sistemi yakınması olan sözleşmeli er ve erbaş askerlerin hastane kayıtlarından elde edilmiştir. Kas iskelet sistemi yaralanmaları vücuttaki lokalizasyonu, oluş mekanizması, yapılan askeri aktivite ile ilişkisi ve yaralanma sonrası oluşan iş gücü kaybı incelenmiştir.600 kişilik askeri popülasyonda görülen kas iskelet sistemi yaralanmaları hastane kayıtlarından tarandı $(\mathrm{n}=108 \% 9,3)$.

Bulgular: En sık diz çevresinin etkilendiği gözlendi $(n=36, \% 33,3)$. Yumuşak doku yaralanması en yaygın olan yaralanma tipi idi. ( $\mathrm{n}=50, \% 46,2)$. Askeri yürüyüşler ve spor aktiviteleri, yaralanmaya sebep olan en yaygın aktivitelerdi $(\mathrm{n}=81 \% 75)$. En çok etkilenen grup 25 yaş ve altıydı(n=52,\%48,1).Yaralanma şiddetine göre iki hafta ile bir yıl arası süre iş gücü kaybı olduğu görüldü.

Tartışma ve Sonuç: Askeri yürüyüşler ve spor aktiviteleri sırasında gelişen yumuşak doku ve diz çevresini ilgilendiren kas iskelet yaralanmalarının önlenmesi için stratejiler geliştirilmelidir.

Anahtar Kelimeler: Ordu, Türk Askeri, Kas İskelet Yaralaması, Askerlik Eğitimi, Diz Yaralanması, Ev Kazaları, Sözleşmeli Askerlik.

DOI: $10.5798 /$ dicletip.988068

Correspondence / Yazışma Adresi: Tuğrul Ergün, Mardin Devlet Hastanesi Ortopedi Ve Travmatoloji Kliniği Artuklu/Mardin, Türkiye e-mail: drergun14@gmail.com 


\title{
Profile of Musculoskeletal Injuries of The Soldiers Who Are Serving As Contracted Soldier And Sergeants
}

\begin{abstract}
Objective: The military profession includes challenging training conditions and common musculoskeletal injuries can be seen. The aim of this study is to profile the common musculoskeletal injuries observed in soldiers serving as contracted soldiers and sergeants within the Turkish Armed Forces (TSK) and to be a source for strategies that can be developed to prevent them.

Methods: Musculoskeletal injuries in the military population people were screened from the hospital records. Musculoskeletal injuries were examined according to their localization in the body, mechanism of occurrence, the relationship between military activity and the loss of work force after the injury.

Results: Musculoskeletal injuries in a military population of 600 were screened from hospital records (n = 108 9.3\%). It was observed that the knee circumference was most frequently affected ( $n=36,33.3 \%)$. Soft tissue injury was the most common type of injury $(n=50,46.2 \%)$. Military walks and sports activities were the most common activities that caused injury $(n=81,75 \%)$. The most affected group was 25 years and younger $(n=52,48.1 \%)$. Two weeks to one year, depending on the severity of injury, workforce loss was observed.
\end{abstract}

Discussion and Conclusion: Strategies should be developed to prevent soft tissue and knee musculoskeletal injuries during military walks and sports activities.

Keywords: Army, Turkish Military, Musculoskeletal Injury, Military Training, Knee Injury, Home Accidents, Contract Military Service.

\section{GíRiş}

Günümüz dünyası, ülkelerin çevik, yetenekli ve güçlü askeri ordulara sahip olmasını gerektirmektedir. Askeri personeldeki spor yaralanmaları ordunun hizmet ve kabiliyet yeteneğini aksatır ${ }^{1,2}$.

Türk Silahlı Kuvvetleri (TSK) çekirdek kadrosu profesyonel askerlerden oluşmakla birlikte, çoğunluğunu düşük rütbeli askeri personel oluşturmaktadır. Fakat son yıllarda, terörle etkin mücadele kapsaminda profesyonel askerlerin oranı gittikçe artmaktadır³. Askeri personelin gerçekleştirdiği aerobik kondisyon ve askeri antrenmanlar sonrası Kas İskelet Sistemi (KIS) yaralanması görülebilmektedir ${ }^{4,5}$. Düşük düzey aerobik kondisyon yapılması askeri personel KİS yaralanmalar için iyi bilinen bir risk faktörüdür6.

Gelişen KIS yaralanmalarında en sık alt ekstremite etkilendiği iyi bilinmektedir 7,8 . Bununla birlikte bu yaralanmalar arasında da en sık ayak bilek ve diz yaralanmaları gözlenmektedir? ${ }^{7}$.

Bu çalışmanın amacı Türk Silahlı Kuvvetleri (TSK) bünyesinde sözleşmeli er ve erbaş olarak görev yapan askerlerde gözlenen yaygın kas iskelet sistemi yaralanmalarının profilini çıkararak bunları önlemeye yönelik geliștirilebilecek stratejilerine kaynak olmaktır.

\section{YÖNTEMLER}

Bu çalışma TSK bünyesinde sözleşmeli er ve erbaş olarak görevli askeri personel popülasyonu üzerinde yapılmıştır. Çalışmaya son 1 yıl içinde rutin sağlık kontrolleri yapılması amaciyla hastaneye başvuran ( $\mathrm{n}=600)$ hasta ve sağlıklı sözleşmeli er ve erbaş askeri personellerin hasta dosyaları dahil edilmişlerdir. KİS yaralanma verilerine hastane PACS sistemi taranarak ulaşılmıştır. Her bir askerin; yaş, yaralanma durumu, yaralanma mekanizması, etkilenen vücut bölgesi, meydana gelen yaralanma tipi, yapılan tedavi ve göreve dönüş süreleri gibi özellikleri hastane PACS 
kayıtlarından kayıt altına alınmıştır. KİS yaralanmaları görev dışı zamanlarda meydana gelen askerler, gene aynı dönem sağlık kontrolleri yapılan güvenlik korucuları ve sağlık kayıtları eksik olan (örneğin; yaralanma tipi) askerler çalışmadan çıkarıldı. Tüm kayıtlar gözden geçirildi ve yinelenen ve uygun olmayan kayıtlar kaldırıldı.

\section{İstatiksel Yöntem}

İstatistik analiz yapmak için Statistical Package for Social Science (SPSS) 22,0 programı kullanıldı. İlk olarak, çalışmanın amacına yönelik verileri incelemek ve tanımlamak için betimsel analizler yapılmıştır. Elde edilen veriler ile en sık görülen yaralanma tipleri ve mekanizmaları belirlenerek literatürdeki benzer çalışmalar ile karşılaştırıldı. Çalışmanın yapılması için yerel etik konseyinden 04.01.2021 tarihinde, (Sayı No: E-37201737806.02.02) onay alındı. Bu veriler geriye dönük olduğundan ve katılımcıların tanımlanamaması ve onay alınamadı̆̆ sebebiyle gönüllü olur formu oluşturulamadı.

\section{BULGULAR VE ANALIZLER}

Son bir yıl içinde yapılan tarama sonucu 600 tane hastane başvuru kaydına ulaşıldı. Örneklemin \%9,3 $(n=108)$ 'nde KİS yaralanması tespit edildi. Yaralanmaların \%42,6 (n=46) vücut sol yarısında olup en sık \%33,3(n=36) oran ile diz çevresi etkilenmiştir. Yaralanmaların \%87(n=94)'si konservatif tedavi ile giderilebilen hafif yaralanmalardan oluşmakta iken, geriye kalan \%13( $n=14)$ ciddi yaralanmalar olup cerrahi tedavi yapıldığı gözlendi. Bir yıl içinde gözlenen yaralanmaların şiddetleri ve vücut bölgesine göre dağılım sıklıkları rapor edildi. (Tablo I ).

Askerlerde meydana gelen KİS yaralanmaları, yaralanma tipine göre sınıflanmıştır (Tablo II). En sık görülen yaralanma tipi 46,2\% (n=50) yumuşak doku yaralanması olarak ortaya çıkmakla birlikte en yaygın \%33 $(n=36)$ diz çevresinin etkilendiğini anlaşılmaktadır. İkinci sıklıkla \%20,3(n=24) oranla ayak bilek yaralanmaları takip etmektedir.

Tablo I: Yaralanma şiddetinin vücut bölgesine göre dağılımı.

\begin{tabular}{|l|l|l|l|}
\hline Lokasyon & $\begin{array}{l}\text { Hafif } \\
\text { Yaralanma }\end{array}$ & $\begin{array}{l}\text { Ciddi } \\
\text { Yaralanma }\end{array}$ & $\begin{array}{l}\text { Hafif ve Ciddi } \\
\text { Yaralanma }\end{array}$ \\
\hline Diz Çevresi & $\begin{array}{l}32 \\
(\% 29,6)\end{array}$ & $4(\% 3,7)$ & $36(\% 33,3)$ \\
\hline Ayak bilek Çevresi & $\begin{array}{l}22 \\
(\% 20,3)\end{array}$ & $2(\% 1,9)$ & $24(\% 22,2)$ \\
\hline Omuz Çevresi & $8(\% 7,4)$ & $2(\% 1,9)$ & $10(\% 9,3)$ \\
\hline Dirsek Çevresi & $10(\% 9,2)$ & $4(\% 3,8)$ & $14(\% 13)$ \\
\hline El bilek Çevresi & $4(\% 3,8)$ & $2(\% 1,9)$ & $6(\% 5,6)$ \\
\hline Omurga Çevresi & $\begin{array}{l}18 \\
(\% 16,7)\end{array}$ & $0(\% 0)$ & $18(\% 16,7)$ \\
\hline Toplam & $94(\% 87)$ & $14(\% 13)$ & $108(\% 100)$ \\
\hline
\end{tabular}

Veriler yaralanma sayı(yaralanma\%) olarak kayıt edildi.

Tablo II: Yaralanma çeşidine göre yaralanma şiddetinin gösterilmesi

\begin{tabular}{|l|l|l|l|}
\hline Yaralanma Tipi & $\begin{array}{l}\text { Hafif } \\
\text { Yaralanma }\end{array}$ & $\begin{array}{l}\text { Ciddi } \\
\text { Yaralanma }\end{array}$ & $\begin{array}{l}\text { Hafif ve Ciddi } \\
\text { Yaralanma }\end{array}$ \\
\hline $\begin{array}{l}\text { Yumuşak Doku } \\
\text { Yaralanması }\end{array}$ & $50(\% 46,2)$ & $0(\% 0)$ & $50(\% 46,2)$ \\
\hline $\begin{array}{l}\text { Vertebral Disk } \\
\text { Patolojisi Silah }\end{array}$ & $2(\% 1,8)$ & $0(\% 0)$ & $2(\% 1,8)$ \\
\hline $\begin{array}{l}\text { Ateşli } \\
\text { Yaralanma }\end{array}$ & $30(\% 27,7)$ & $4(\% 3,7)$ & $34(\% 31,4)$ \\
\hline $\begin{array}{l}\text { Eklem ve Ligament } \\
\text { yaralanması }\end{array}$ & $4(\% 3,7)$ & $8(\% 7,4)$ & $12(\% 11,1)$ \\
\hline Kemik Kırı̆̆ & $94(\% 87)$ & $14(\% 14,8)$ & $108(\% 100)$ \\
\hline Toplam & $3(\%, 25)$ \\
\hline
\end{tabular}

Yaralanma esnasında yapılan aktiviteler tablo III de belirtilmiştir. En sık yaralanma eğitim yürüyüşü (Marş) esnasında geliştiği görülmektedir. Spor esnasında yaralanma ikinci en sık yaralanma olarak ortaya çıkmaktadır. İki durum birlikte tüm yaralanmaların $\% 75$ (81/108) ini oluşturmaktadır. 
Tablo III: Yaralanma şiddetini belirleyen aktiviteler kayıt edilmiştir.

\begin{tabular}{|l|l|l|}
\hline Yaralanma Mekanizması & $\begin{array}{l}\text { Hafif } \\
\text { Yaralanma }\end{array}$ & Ciddi Yaralanma \\
\hline Yürüyüş(Marş) & $52(\% 55,3)$ & $1(\% 0,9)$ \\
\hline Spor & $24(\% 25,5)$ & $4(\% 3,6)$ \\
\hline Devriye & $12(\% 12,7)$ & $3(\% 2,7)$ \\
\hline Operasyon & $6(\% 6,3)$ & $6(\% 5,4)$ \\
\hline
\end{tabular}

Örneklemde KİS yaralanmasina sahip olan askeri personelin yaş ortalaması $26,3 \pm 4,1$ yl olup, yaş aralığı 20 ile 44 yıl idi. Yaralanmaların $\% 48,1(\mathrm{n}=52) 25$ yaş altı askeri personelden oluşmakta iken \%12,9 (n=14) 30 yaş üstü personelden oluşmaktadır (Tablo IV).

Tablo IV: KİS Yaralanmaların Yaşa Göre Dağılımı.

\begin{tabular}{|l|l|l|}
\hline Yaş Aralığı & Sayı(n) & Yüzde(\%) \\
\hline$<25$ & 52 & $\% 48,1$ \\
\hline $25-29$ & 42 & $\% 38,9$ \\
\hline $30-35$ & 12 & $\% 11$ \\
\hline$>35$ & 2 & $\% 1,90$ \\
\hline
\end{tabular}

Örneklemde KIS yaralanması olan hastaların yaralanma tipine iş gücü kaybı olmuştur. İş gücü kaybı yașayan askerlerin sayıları ve ișe dönüș süreleri Tablo $V$ 'te rapor edilmiștir.

Tablo V: Askeri Personelde İş Gücü Kaybı

\begin{tabular}{|c|c|c|}
\hline \multicolumn{3}{|c|}{ İŞ GÜCÜ KAYBI } \\
\hline & Sayı(n) & Yüzde(\%) \\
\hline 0-2 (hafta) & 30 & $\% 27,8$ \\
\hline 2-4(hafta) & 20 & $\% 18,5$ \\
\hline 1-3 (ay) & 30 & $\% 27,8$ \\
\hline 3-6 (ay) & 22 & $\% 20,4$ \\
\hline $6-12$ (ay) & 6 & $\% 5,6$ \\
\hline
\end{tabular}

\section{TARTIŞMA}

Bu çalışmada amacımız TSK'da sözleşmeli er ve erbaş olarak görev alan askeri personelinde görülen KİS yaralanmalarını, sıklığını, etkilenen ekstremite bölgesini ve oluş mekanizmalarını birlikte inceleyerek, gelişen KiS yaralanmaların önlenmesi amacıyla geliştirilebilecek stratejilere kaynak olmaktır. Çalışmamız TSK askeri personelinin etkin olarak askeri operasyonlar sürdürdüğü ülkemizin Güneydoğu Bölgesinde çalışan sözleşmeli er ve erbaş olarak görevli askeri personelinde görülen KİS yaralanmalarının bir yıllık kesitsel bir analizidir. Bildiğimiz kadarıyla, literatürde benzer çalışmalar olmasına rağmen TSK askeri personelinde ortaya çıkan KIS yaralanmalarını inceleyen ülkemizde yapılan ilk çalıșma olma niteliğindedir.

Örneklemimizde $\% 9,3$ oranında Kis yaralanması tespit edilmiş olup, bu çalışmada dikkat çeken sonuçlardan biri TSK sözleşmeli er ve erbaş askeri personelde Kis yaralanmalarında en sık $(\% 33,3)$ etkilenen vücut bölümü diz çevresi olarak ortaya çıkmıştır. Pope ve ark, tam zamanlı ve yarı zamanlı çalışan askeri personelde ortaya çıkan KIS yaralanmalarını inceleyen çalışmalarında $\% 16,7$ oranında KİS yaralanma olduğunu rapor etmişlerdir9. Literatürde yapılan birçok çalışmada askeri personel KIS yaralanmalarında en sık olarak alt ekstremite ve bunların içinde de diz bölgesinin etkilendiği rapor edilmiştir2,10,11.

Schram ve ark. çalışmalarında tüm yaralanmalar içinde en sık $(\% 15,9)$ diz çevresinin etkilendiğini, bunu takiben $(\% 9,8)$ ayak bilek yaralanmaları olduğunu bildirmişlerdir ${ }^{2}$ Wilkonson ve ark. çalışmalarında İngiliz ordusu içinde askeri yaralanmaları ve risk faktörlerini incelediği çalışmasında en sık (\%19) diz yaralanmaları olarak rapor etmiştir ${ }^{11}$. Knapik'in çalışmasında en sık yaralanma $\% 20$ olarak ayak ve ayak bileği olarak rapor edilmiştir ${ }^{6}$. Bizim çalışmada ayak bilek yaralanmaları ikinci sırada $(\% 22,2)$ yer almaktadır (Tablo I ). 
Çalışmamızda sözleşmeli er ve erbaş askeri personelde en sık KİS yaralanma \%46,2 yumuşak doku yaralanması şeklinde olduğu görüldü. $\mathrm{Bu}$ tip yaralanmanın yüksek çıkması vücudun her bölgesinde görülebilmesinden dolayı olmuş olabilir. Hill ve ark. çalışmalarında askeri personelde diz çevresi yumuşak doku yaralanmaların inceledikleri çalışmalarında ileri yaş, diz, ayak bilek ve kalça travma öyküsü olması ve 30 yaş üstü personellerde diz çevresi yumuşak doku yaralanmalarının daha fazla olduğunu rapor etmişlerdir ${ }^{12}$. Askeri öğrenciler üzerinde yapılan bir çalıșmada daha önce KİS yaralanma öyküsü olan ögrencilerde tekrardan KIS yaralanması görülme riskin daha fazla olduğunu rapor etmiştir (RR=1.74 [1.55, 1.94] ${ }^{13}$.Çalıșmamızda yaralanmaların büyük bir bölümü $(\% 48,1) 25$ yaş altında ve alt ekstremitede yer almaktadır. Robinson ve ark. askeri personelde görülen KİS yaralanmaların çoğunluğu alt ekstremitede görülmekle birlikte, ikinci sıklıkla kas sprain yaralamaları olduğunu bildirmiştir ${ }^{14}$. Çalışmamızda da bu çalışmaya ikinci sıklıkta eklem ve ligament yaralanması olduğu ortaya çıkmıştır.

Çalışmamızda en sık yaralanma mekanizması \%54 askeri eğitim yürüyüşleri esnasında yaralanmaların geliştiğini gözlemledik. Literatürde birçok çalışmada en sık antremanlar esnasında KİS yaralanmaların ortaya çıktığı rapor edilmiştir4,15. Wilkonson ve ark. çalışmalarında \%52 sportif aktivitelerine bağlı askeri yaralanmalar rapor etmişlerdir ${ }^{11}$. Andrade ve ark. en sik yaralanma mekanizmasını akut travma sonucu ve üçüncü sırada da spor aktiviteleri olarak bildirmiştir ${ }^{16}$. Çalışmamızda spor aktiviteleri ikinci sırada (\%28) yer almaktadır.

Çalışmamızda elde edilen veriler ışı̆̆ında askeri personelde karşılaşılan KİS yaralanmaları askeri personelde sıhhat, zaman ve işgücü kaybına yol açmaktadır. Çalışmamızda askeri personelde $\% 46,3$ oranında $0-4$ hafta ve $\% 271$ 3 ay süre iş gücü kaybına uğradığı ortaya çıkmıştır (Tablo V). Askeri KİS yaralanmaları iş yerinde olması sebebiyle iş kazası niteliğindedir. Yapılan bir çalıșmada iș kazaların otuz yaş üzerinde daha sık görüldüğü rapor edilmiştir ${ }^{17}$. Çalışmamızda en sık 20-25 yaş aralığındaki askeri personel etkilenmiştir (Tablo IV). Bu durumu genç askerlerin, daha yoğun antreman yapmasından kaynaklandığını düşünmekteyiz.

Askeri KIS yaralanmaların azaltmak amacıyla literatürde önerilen stratejiler olmakla birlikte fikir birliğine varılamamıştır. Kollock ve ark. meta-analiz çalışmasında, askeri spor eğitimlerimde yapılan baldır ve kalça egzersizleri ile diz çevresi yaralanmaları arasında olası bir bağlantı olduğunu göstermektedir ${ }^{17}$. Egzersiz öncesi uygulan germe-ısınma hareketlerinin yaralanma riskini azatlı̆̆ $\mathrm{da}$ söylenemez ${ }^{9,18}$. Diğer yandan Goodball ve ark. askeri eğitimde uygulanan denge ve dayanıklılık egzersizlerinin KİS yaralanmalarını azaltmadığını rapor etmişlerdir $^{19}$. Yapılan bir çalışmada sportif faaliyetlerde kullanılan uygun ekipman ve vitamin takviyeleri yapılması KIS yaralanmalarını azaltabileceği rapor edilmiştir 5,14,20. Askeri eğitimde uygun ekipman kullanılması ve personelin yaralanmalar hakkında bilinç düzeyinin artırılmasının KİS yaralanmalarını azaltacağını düşünmekteyiz.

Çalıșmamızın limitasyonları, çalışmamız son 1 yll içinde başvuran askeri personelin hastane hasta dosyaları kapsaması sebebiyle hastane kayıtlarına bağımlı kalınmış olup KİS yaralanması esnasında hastaların anamnez ve fizik muayene bilgilerinin kısıtlı olmuştur. Ayrıca eğitimde etkilenen personel ile görevde etkilenen personel aynı kapsamda ele alınmış olup ayırt edilememiștir. Hasta popülasyonu heterojendir.

\section{SONUÇ}

TSK'da sözleşmeli er ve erbaş olarak görevli askeri personellerde en sık diz çevresi yumuşak 
doku yaralanmaları ortaya çıkmaktadır. $\mathrm{Bu}$ durum çoğunlukla yaygın iş gücü kaybına sebep olmakla birlikte, yaş olarak daha düşük olan askerileri etkilemektedir. En sık eğitim yürüyüşleri ve spor aktiviteleri esnasında ortaya çıkmaktadır. Bu yaralanmaları azaltmak için önlemler alınmalıdır.

Teşekkür: Çalışmanın katılımcılarına teşekkürlerimizi sunarız.

Etik Kurul Kararı: Sağlık Bakanlığı Mardin İl Sağlık Müdürlüğü Etik Kurulu (04.01.2021 Sayı 806).

Çıkar Çatışması Beyanı: Yazarlar çıkar çatışması olmadığını bildirmişlerdir.

Finansal Destek: Bu çalışma her hangi bir fon tarafından desteklenmemiştir.

Declaration of Conflicting Interests: The authors declare that they have no conflict of interest.

Financial Disclosure: No financial support was received

\section{KAYNAKLAR}

1. Kaufman KR., Brodine S., Shaffer R. Military training-related injuries: surveillance, research, and prevention. Am J Prev Med. 2000; 18: 54-63.

2. Schram B., Orr R., Pope R. A Profile of Knee Injuries Suffered by Australian Army Reserve Soldiers. Int J Environ Res Public Health. 2019; 16: 12.

3. Özgen C. Türk Silahli Kuvvetleri'nde Profesyonelleşme Çalişmalari. Trakya Üniversitesi Sosyal Bilimler Dergisi. 2011; 13: 202-19.

4. Cameron K., L Owens. The burden and management of sports-related musculoskeletal injuries and conditions within the US military. Clin Sports Med. 2014; 33: 573-89.

5. Grier T., Canham-Chervak M., McNulty V., Jones B. H. Extreme conditioning programs and injury risk in a US Army Brigade Combat Team. US Army Med. Depart. J. 2013; 20: 213-18.

6. Knapik J. J., Sharp M. A., Canham-Chervak M. I. C. H. E. L. L. E., et al. Risk factors for training-related injuries among men and women in basic combat training. Med Sci Sports Exerc. 2001; 33: 946-54.

7. Cameron K. L., Owens B. D., De Berardino T. M. Incidence of ankle sprains among active-duty members of the United States Armed Services from 1998 through 2006. J Athl Train. 2010 ;45: 29-38.

8. McDonald D., Orr R. M., Pope R. A. Comparison of work health and safety incidents and injuries in part-time and full-time Australian Army personnel. J Mil Veterans Health. 2016; 51: 880-86.

9. Pope R., Orr R. Incidence rates for work health and safety incidents and injuries in Australian Army reserve vs full time soldiers, and a comparison of reporting systems.M. Garr. Health Serv. 2017 ;25: 16-88.

10. Rump A., Becker B., Eder S., et al. Medical management of victims contaminated with radionuclides after a "dirty bomb" attack. Mil Med Res. 2018; 5: 1-10.

11. Wilkinson D. M., Blacker S. D., Richmond V. L., et al. Injuries and injury risk factors among British army infantry soldiers during predeployment training. Inj Prev. 2011; 17: 381-87.

12. Hill O. T., Bulathsinhala, L., Scofield D. E., Haley T. F., Bernasek T. L. Risk factors for soft tissue knee injuries in active duty US Army soldiers, 2000-2005. Mil Med. 2013; 178: 676-82.

13. Kucera K. L., Marshall S. W., Wolf S. H., et al. Association of injury history and incident injury in cadet basic military training. Med Sci Sports Exerc. 2016; 48: 1053.

14. Robinson M., Siddall A., Bilzon J., et al. Low fitness, low body mass and prior injury predict injury risk during military recruit training: a prospective cohort study in the British Army. BMJ Open. 2016; 2:1

15. Arslan I. G., Dijksma I., van Etten-Jamaludin, F. S., Lucas, C., Stuiver M. M. Nonexercise interventions for prevention of musculoskeletal injuries in armed forces: a systematic review and meta-analysis. Am J Prev Med. 2020; 5:7-11.

16. De Andrade Gomes M.Z., Pinfildi C.E. Prevalence of musculoskeletal injuries and a proposal for neuromuscular training to prevent lower limb 
injuries in Brazilian Army soldiers: an observational study. Mil Med Res. 2018; 5: 1-7.

17. Avınca Ö., Dursun R., Taș M., Üstündağ M., Orak M., Güloğlu, C. Diyarbakir Ilinde Meydana Gelen Is Kazalarinin Demografik Analizi, Mortalite ve Morbiditeyi Etkileyen Faktörler. Dicle Med J. 2020; 47: 645-55.

18. Kollock, R. O., Andrews C., Johnston A., et al. A meta-analysis to determine if lower extremity muscle strengthening should be included in military knee overuse injury-prevention programs. J Athl Train. 2016; 51: 919-26.

19. Dijksma I., Arslan I. G., van Etten-Jamaludin F. S., et al. Exercise Programs to Reduce the Risk of
Musculoskeletal Injuries in Military Personnel: A Systematic Review and Meta-Analysis. PM\&R. 2020; 12: 1028-37.

20. Goodall R. L., Pope R. P., Coyle J. A., Neumayer, R. Balance and agility training does not always decrease lower limb injury risks: a clusterrandomised controlled trial. Int J Inj Contr Saf Promot. 2013; 20: 271-81.

21. Bonanno D. R., Landorf K. B., Munteanu S. E., Murley G. S., Menz H. B. Effectiveness of foot orthoses and shock-absorbing insoles for the prevention of injury: a systematic review and metaanalysis. Br J Sports Med. 2017; 51: 86-96. 